\title{
The Newspaper, the Mirror, and the Kaleidoscope-Three Assets in Teaching and Writing
}

\author{
Cam Caldwell ${ }^{1}$, Nikolina Ljepava ${ }^{1} \&$ Verl Anderson ${ }^{2}$ \\ ${ }^{1}$ American University in the Emirates, United Arab Emirates \\ ${ }^{2}$ Dixie State University, USA \\ Correspondence: Cam Caldwell, American University in the Emirates, United Arab Emirates.
}

Received: November 17, $2020 \quad$ Accepted: December 27, $2020 \quad$ Online Published: December 31, 2020

doi:10.5430/bmr.v9n4p28

URL: https://doi.org/10.5430/bmr.v9n4p28

\begin{abstract}
Introduction: In the context of the 21 st century, business faculty have found that the challenges associated with teaching effectively and becoming published authors can be ominous and sometimes frustrating. This paper identifies how the newspaper, the mirror, and the kaleidoscope can be useful assets in helping faculty to focus their teaching and enhance the likelihood that they can publish their scholarly research. The paper includes five suggestions for faculty to consider as they apply these three tools.
\end{abstract}

Objective: This paper provides helpful insights for business faculty as they seek to improve their teaching effectiveness and their ability to provide examples in publishable academic papers.

Methods: Specific examples are provided of the use of the newspaper, the mirror, and the kaleidoscope for business scholars.

Results: Five suggestions are provided to facilitate effective teaching and writing.

Conclusions: Effective teaching and being published in scholarly journals can be daunting challenges and this paper provides valuable suggestions for improving teaching and writing success.

Keywords: improving business teaching, business research writing, tools for business faculty success, faculty development

\section{Introduction}

The two challenges facing many faculty members today are to teach effectively in the classroom and to write well enough to become widely published scholars. Those two skill sets enable faculty 1) to attract and retain the students' attention long enough for them to decide that they want to learn, and 2) to convey their research to colleagues and readers in a form that reviewers and editors will value and that readers will be able to apply.

The purpose of this paper is to suggest three assets or tools that have practical value for college and university faculty members who want to improve their ability to become more successful in the classroom and more appreciated as academics scholars in their fields. The value of these assets is that they enable faculty members to improve the interest appeal of their teaching and the practical value of their academic insights.

The three assets -- the newspaper, the mirror, and the kaleidoscope - that are identified in this paper may not immediately come to mind as highly-regarded resources to most faculty members, but they nonetheless can play powerful roles in improving teaching quality and in writing a publishable journal article or book. This paper incorporates well-respected academic research about teaching and publishing as aids in helping faculty members to assisting their students to learn and in becoming published scholars. It concludes with five suggestions for faculty to consider as they strive to improve their skills and how they are perceived by their students and their peers.

\section{Importance of Teaching and Publishing}

In assessing business faculty competencies for retention, promotion, or tenure, the skills of teaching and publishing are typically the two most important criteria that are evaluated in assessing faculty success (Bedford, 2020). Although the title of a recent Chronicle of Higher Education article declared “Assessment is an Enormous Waste of Time” (Gilbert, 
2019), student evaluations of teaching effectiveness have historically been the primary means of evaluating faculty teaching competency (Chen \& Hoshower, 2003).

The current makeup and context of business students at many colleges and universities can be a major factor that makes teaching difficult. Generation $\mathrm{Z}$ students often have short attention spans and a desire to be entertained as well as educated (Elmore \& McPeak, 2019) - in addition to having a strong preference and affinity for high technology in the classroom (Cilliers, 2017; Singh, 2014).

Teaching working professionals who frequently make up graduate business courses can a completely different challenge because of those students' high expectations about teaching quality and because of their sometimes-misguided belief that they already understand everything about business topics in their field of employment (Mintzberg, 2005). In the current pandemic environment requiring online teaching, the challenge of teaching via the online format is, for many faculty members, even more difficult (Gillett-Swan, 2017; Jacobs, 2013).

Becoming published in highly-respected scholarly journals is also difficult for many faculty and the task of writing a top-quality academic paper can be harder when faculty members face the unfamiliar conditions of dealing on a more regular basis with their isolated families, learning the ins and outs of teaching in the new online format required by COVID-19, and taking on the new role of "home school teacher" in addition to the expanded obligations of "online college instructor" (Johnson, Veletsianos \& Seaman, 2020; DePietro, 2020).

Becoming a published scholar is a challenge, even for the many faculty who have graduated from top-quality institutions - according to David Whetten (2001), former President of the Academy of Management. Although Whetten ultimately distinguished himself as an eminent scholar, he poignantly recounted his struggles to publish during his first three years at the University of Illinois in his first academic appointment. After Whetten (1989) was appointed editor of the prestigious Academy of Management Review, he wrote an often-cited article titled "What Constitutes a Theoretical Contribution" in which he offered would-be scholars advice about effective writing.

The challenge to write effectively and to be published in academic journals presents many stumbling blocks that must be understood and overcome if business faculty are to learn the lessons that Whetten learned in his initial struggles (Caldwell, 2018). Fortunately, there are three useful assets that can help business faculty to become both more skillful teachers and more published authors.

\section{Utilizing the Newspaper}

As a resource for improving teaching relevance and making scholarly publications more practical in their application, the newspaper - whether in paper or digital form - can be a valuable asset. Will Rogers - the highly popular vaudeville performer and humorist of the 1930s - frequently told his audiences, "All I know is just what I read in the newspaper" (O’Brien, 2019). Often labeled, "the cowboy philosopher, Rogers, was one of the most highly regarded entertainers and political commentators of his era. He often told his audiences that the newspaper provided him with all of the material that he needed for his comedy routines. Rogers regularly made fun of politicians and public figures with "harsh and amusing truths" that were funny, shocking, and true (Rogers, 2001).

In addition to being the source of current economic and business news, a newspaper continues to provide a source of humorous and interesting stories that can add human interest and teach important lessons in the business classroom (Dieter, 2000). Citing current major news stories in the Wall Street Journal or the Washington Post can be an effective way of pointing out the practical value of lecture content and core business principles (Becker, 2000).

Business news items can also be an effective means of demonstrating the importance of an academic journal article. The relevance and practical contribution of business research is enhanced when applied to issues that make an important difference in individual lives. Business research, often criticized as being impractical and irrelevant, is more likely to generate reviewer approval when it applies to current issues that are salient to readers and ethically important (Jones, 1991).

Henry Mintzberg, a critic of impractical business research, offers the "Bill and Barbara Test" for assessing the contributing value of business journal publications. Bill and Barbara are two practitioners to whom Mintzberg gives academic journal articles and who rate those articles in terms of their value to the business world (Mintzberg \& Caldwell, 2017). Mintzberg counsels that would-be academic scholars would do well to focus on the practical value of that which they write about. Mintzberg's opinion is shared by David Whetten in his 1989 counsel to readers (Whetten, 1989) - as well as other noted business research scholars (Hair, Page \& Brunsveld, 2019). 


\section{Incorporating the Mirror}

Business faculty can use the metaphor of the mirror in a variety of ways to improve the quality of their classroom teaching. A mirror reflects oneself and the ability to examine one's identity, self-deceptions, and hidden nature. Great insights can be discovered when we honestly engage in self-assessment (Caldwell, 2009). Looking into a mirror and examining their own beliefs and values can enable faculty members to reflect more fully on the core values that underlie the principles that they teach (Burke \& Stets, 2009). Being committed to those values and ideals and teaching with passion can help faculty to be more effective instructors - especially when that passion is matched with careful preparation of teaching materials (Nicole \& Releford, 2020).

Holding up a mirror for students, so that they can thoughtfully examine their own beliefs and values, is an important teaching technique and greatly increases student learning and the application of their attitudes and values in the learning process (Fink, 2013). Students who integrate principles of affective learning, examine their own values, and assess how they intend to apply what they are learning can increase their ability to learn new concepts (Glasper \& Caldwell, 2016).

Asking students to "look into the mirror" to examine their own ethical lens and to define their personal goals associated with course learning ideas also enables those students to become more fully aware of how they wish to apply their education. That same self-awareness process can help students to reflect on their moral obligations as leaders (Eriksen, 2009) and become more deeply committed to their own social responsibility obligations and ethical priorities (Anderson, Ndalamba, \& Caldwell, 2017).

The metaphor of the mirror is also a powerful factor for faculty who seek to become published scholars. Quality of writing is enhanced when individuals write about topics that they care deeply about on a personal level (Gill, 2014). That personal passion can be a powerful difference maker in achieving any sought-after objective, can measurably increase commitment to achieving a goal, and can exponentially improve the level of one's personal performance (Duckworth, 2018).

Looking into one's own mirror can enable an academic writer to address seven important value-based criteria which Whetten (1989, p. 494-495) identified in the form of a serious of self-assessment questions. Whetten indicated that addressing each of these seven questions was important to reviewers in evaluating whether a paper was publishable.

1) What's New? How does the paper topic relate to current ideas in the field?

2) So What? Why is the topic important to others and why does the topic matter?

3) Why So? Is the paper logical in making its arguments?

4) Well Done? Is the paper complete and thorough and meet professional standards of writing quality?

5) Done Well? Is the writing free of grammatical errors, properly transitioned, and flow smoothly?

6) Why Now? Does the paper contribute to the current discussion of important issues?

7) Who Cares? How does the paper impact society in ways that actually matter?

The answers to each of these seven questions become clearer when individual writers focus on the importance of what matters to them (Gill, 2014).

\section{Understanding the Kaleidoscope}

A kaleidoscope is an optical instrument made up of two or more mirrors set up so that objects on one end of the mirrors are seen as a symmetrical pattern when viewed from the other end, due to the repeated reflection of the image. These mirrors are enclosed in a tube with one end containing colored pieces of glass or similar materials which are reflected into the viewed pattern. Rotation of the tube causes the glass to relocate - resulting in an ever-changing set of patterns (Kohler, 2012).

The metaphor of the kaleidoscope has practical applications for business faculty who seek to improve their teaching and writing. Though often considered as a simple children's toy, the kaleidoscope first had its roots in the $16^{\text {th }}$ century (Newlin, 1899). The kaleidoscope was introduced three centuries later by Sir David Brewster (Brewster, 2017) as a scientific and artistic device of interest to others which possessed value because of "the infinity of patterns" that a kaleidoscope can create.

As a teaching resource, the idea of the kaleidoscope's use of limited resources to create a multitude of options has many practical applications. For example, the "Magic Triangle" learning game can reinforce to students the practical application of the kaleidoscope and the benefits of creative thinking as an important skill of business students (Cloud 
Foundry, 2011). The utilization of learning games not only can capture the attention of easily bored Generation Z students but can have easily recognized practical value for working professionals - and many learning games can be a powerful way of "spicing up" online courses as well (Ritzko \& Robinson, 2006).

The kaleidoscope concept also offers valuable benefits to business faculty seeking to be published. Developing new ways to present research ideas enables scholars to add value to the body of knowledge in their fields and creates added value for practitioners as well (Timmer, 1998). The kaleidoscope's ability to create new patterns and images correlates with the scholar's ability to combine ideas in new ways.

Just as adding a new piece of colored glass to the kaleidoscope can exponentially expand the number of new patterns, as scholars add areas of new expertise to their knowledge portfolio, they can use that knowledge in a multitude of ways to generate new ways of looking at solutions or examining possibilities (Christensen, 2016). This "disruptive innovation" approach to scholarly research is a well-respected key to generating important new ideas (Christensen \& Eyring, 2011) - just as this same approach to thinking in new ways has proven so successful as a principle of strategic advantage in the global marketplace. (Christensen \& Raynor, 2013).

\section{Applying the Tools}

As faculty members contemplate how they can most effectively apply the newspaper, the mirror, and the kaleidoscope to improve their teaching and research, the evidence affirms that the most successful approach begins "from the inside out" (Covey, 2004). The following are five suggestions for business faculty to consider in applying these three tools.

\subsection{Conduct an In-Depth Personal Assessment}

By conducting an in-depth personal self-assessment and becoming fully aware of their own priorities and needs, business faculty are able to identify their strengths, the relationship between those strengths and their approach to teaching and research, and identify hidden insights about their potential about which they may not have previously been fully aware (Urdang, 2010).

\subsection{Formalize Your Mission, Purpose, and Calling}

Writing down a formal purpose statement and defining one's mission and calling in life provide individuals with the focus and direction to achieve their highest potential (Covey, 2013). Achieving the best version of who one can become is a source of tremendous personal gratification - and is a by-product of defining one's "voice" (Covey, 2004; Maslow, 2011).

\subsection{Develop Goals that Matter to You}

Goal setting is universally recognized as helpful, but it especially important for business faculty to set goals that they are passionate about and personally committed to achieving (Duckworth, 2018). When individuals love what they do and are passionate about achieving goals, work becomes a source of great joy - rather than a burden (Covey, 2004).. Goals should be both instrumental, or outcome-based, and normative, or value-based, and should reflect the desires of the heart to be truly motivating (Maslow, 1994).

\subsection{Build In Metrics for Measuring Successes}

Creating a step-by-step plan that translates dreams into action is widely acknowledged as a key to accomplishing great goals (Vallarand, Salvy \& Mageau, Elliot, Denis, Grouzet \& Blanchard, 2007). Metrics for success are most effective when they include specific tasks to be achieved and the results sought after by accomplishing those tasks (Drucker, 2006).

\subsection{Establish Celebration Rewards as Your Personal Incentive}

Identifying a personally gratifying reward or celebration for improving teaching effectiveness or publishing a journal article or book provides a well-deserved incentive for a worthy achievement and is a well-established practice (Scholtes, Joiner \& Streibel, 2018). The motivation to achieve goals that serve others, improve society, and fulfill personal priorities can be spurred by creating both intrinsic and extrinsic reasons for celebration (Caldwell \& Anderson, 2020).

These five steps are widely recognized for their ability to empower individuals to achieve important priorities and apply for business faculty - as well as for the students with whom they work.

\section{Conclusion}

When business faculty enjoy their work and feel confident in their abilities, they increase their ability to make a substantial contribution to the schools where they work, the students that they guide, and the profession in which they 
labor. Although teaching business courses and writing publishable research are not easy tasks, the use of the three tools identified in this paper can help those faculty to be successful.

By thoughtfully identifying how the newspaper, the mirror, and the kaleidoscope can apply to them, individual faculty members can expand their ability to add value in the classroom and in the research that they conduct. The five suggestions included in this paper, while universal in their application, can significantly improve the ability of business faculty members to raise the bar of their performance and achieve greater enjoyment while adding greater value to society.

\section{References}

Anderson, V., Ndalamba, K. K., \& Caldwell, C. (2017). Social responsibility in a troubled world. International Journal of Public Leadership, 13(2), 98-115. https://doi.org/10.1108/IJPL-10-2016-0034

Becker, W. E. (2000). Teaching economics in the 21st century. Journal of Economic Perspectives, 14(1), 109-119. https://doi.org/10.1257/jep.14.1.109

Bedford, D. A. (2020). Fair Process in Assessing the Quality of University Faculty. In N. Baporikar \& M. Sony (Eds.), Quality Management Principles and Policies in Higher Education (pp. 156-187). Hershey, PA: IGI Global, c2020, https://doi.org/10.4018/978-1-7998-1017-9.ch009

Brewster, D. (1858). The Kaleidoscope: Its History, Theory and Construction: with Its Application to the Fine and Useful Arts. J. Murray.

Brewster, G. (1899). Simple Kaleidoscopes: 24 Spectacular Scopes to Make. New York: Lark Books, c1899.

Burke, P. J., \& Stets, J. E. (2009). Identity theory. Oxford University Press. https://doi.org/10.1093/acprof:oso/9780195388275.001.0001

Caldwell, C. (2009). Identity, self-awareness, and self-deception: Ethical implications for leaders and organizations. Journal of Business Ethics, 90(3), 393-406. https://doi.org/10.1007/s10551-010-0424-2

Caldwell, C. (2018). Writing a Publishable Paper: Principles, Questions, Realities, and Stumbling Blocks. Business and Management Research, 7(2), 10-16 https://doi.org/10.5430/bmr.v7n2p10

Caldwell, C, \& Anderson, V. (Eds., 2020). Motivation and Self-Fulfillment. Hauppage, New York: NOVA Publishing.

Chen, Y., \& Hoshower, L. B. (2003). Student evaluation of teaching effectiveness: An assessment of student perception and motivation. Assessment \& evaluation in higher education, 28(1), 71-88. https://doi.org/10.1080/02602930301683

Cilliers, E. J. (2017). The challenge of teaching generation Z. PEOPLE: International Journal of Social Sciences, 3(1). https://doi.org/10.20319/pijss.2017.31.188198

Cloud Foundry. Explaining the Magic Triangle. vmware, Retrieved August 21, 2020, from https://tanzu.vmware.com/content/blog/explaining-the-magic-triangle.

Christensen, C. M. (2013). The innovator's dilemma: when new technologies cause great firms to fail. Harvard Business Review Press.

Christensen, C. M., \& Eyring, H. J. (2011). The innovative university: Changing the DNA of higher education from the inside out. John Wiley \& Sons.

Christensen, C., \& Raynor, M. (2013). The innovator's solution: Creating and sustaining successful growth. Harvard Business Review Press.

Covey, S. R. (2013). The 7 habits of highly effective people: Powerful lessons in personal change. Simon and Schuster.

Covey, S. R. (2013). The 8th habit: From effectiveness to greatness. Simon and Schuster.

DePietro, A. Here's a look at the impact of coronavirus (COVID-19) on colleges and universities in the US Forbes. Retrieved August 20, 2020, from https://www.forbes.com/sites/andrewdepietro/2020/04/30/impact-coronavirus-covid-19-colleges-universities/\#3 $170441861 \mathrm{a} 6$

Deiter, R. (2000). The use of humor as a teaching tool in the college classroom. NACTA journal, 20-28. 
Drucker, P. F. (2006). Managing for Results. New York: HarperCollins.

Duckworth, A., \& Duckworth, A. (2016). Grit: The power of passion and perseverance (Vol. 234). New York, NY: Scribner.

Eriksen, M. (2009). Authentic leadership: Practical reflexivity, self-awareness, and self-authorship. Journal of Management Education, 33(6), 747-771. https://doi.org/10.1177/1052562909339307

Fink, L. D. (2013). Creating significant learning experiences: An integrated approach to designing college courses. John Wiley \& Sons.

Elmore, T., \& McPeak, A. (2019). Generation Z unfiltered: Facing nine hidden challenges of the most anxious population. Poet Gardner.

Gill, C. M. (2014). Effective Writing for College and Beyond. Cincinnati, OH: Writer's Digest Books.

Gillett-Swan, J. (2017). The challenges of online learning: Supporting and engaging the isolated learner. Journal of Learning Design, 10(1), 20-30. https://doi.org/10.5204/jld.v9i3.293

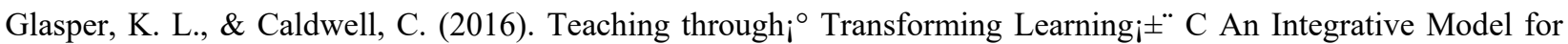
Business and Public Administration Education. Business and Management Research, 5(1), 19-28. https://doi.org/10.5430/bmr.v5n1p19

Hair Jr, J. F., Page, M., \& Brunsveld, N. (2019). Essentials of business research methods. Routledge. https://doi.org/10.4324/9780429203374

Jacobs, P. (2013). The challenges of online courses for the instructor. Retrieved from https://digitalcommons.sacredheart.edu/cgi/viewcontent.cgi?referer=https://scholar.google.com/\&httpsredir=1\& article $=1007 \&$ context $=$ cj_fac.

Johnson, N., Veletsianos, G., \& Seaman, J. (2020). US Faculty and Administrators' Experiences and Approaches in the Early Weeks of the COVID-19 Pandemic. Online Learning, 24(2), 6-21. https://doi.org/10.24059/olj.v24i2.2285

Jones, T. M. (1991). Ethical decision making by individuals in organizations: An issue-contingent model. Academy of management review, 16(2), 366-395. https://doi.org/10.5465/amr.1991.4278958

Kohler, K. (2020). Frequently Asked Questions. KaleidoscopeCollector.com. Retrieved August 21, 2020, from http://www.kaleidoscopecollector.com/faq.htm

Maslow, A. H. (2011). Toward a psychology of being. Simon and Schuster.

Maslow, A. H. (1994). Religions, values, and peak-experiences. Columbus: Ohio State University Press.

Mintzberg, H. (2004). Managers, not MBAs: A hard look at the soft practice of managing and management development. Berrett-Koehler Publishers.

Nicole, F., \& Releford, J. (2020). Be That Teacher: Reigniting the Passion for Teaching and Learning. Savannah, GA: Felicia Nicole.

O'Brien, P. J. (2019). Will Rogers: Ambassador of Good Will, Prince of Wit and Wisdom. Vancouver, B. C., Canada: Red Kestrel Books.

Ritzko, J. M., \& Robinson, S. (2006). Using games to increase active learning. Journal of College Teaching \& Learning (TLC), 3(6). https://doi.org/10.19030/tlc.v3i6.1709

Rogers, W. (2001). The Illiterate Digest. Amsterdam, Netherlands: Fredonia Books.

Scholtes, J., \& Streibel, B. (2018). The TEAM Handbook (3rd ed.). Methuen, MA: GOAL/QPC, c2018.

Timmer, C. P. (1998). Adding value through policy-oriented research: reflections of a scholar-practitioner (No. 590-2016-39892). International Food Policy Research Institute.

Urdang, E. (2010). Awareness of self-A critical tool. Social Work Education, 29(5), 523-538. https://doi.org/10.1080/02615470903164950

Vallerand, R. J., Salvy, S. J., Mageau, G. A., Elliot, A. J., Denis, P. L., Grouzet, F. M., \& Blanchard, C. (2007). On the role of passion in performance. Journal of personality, 75(3), 505-534. https://doi.org/10.1111/j.1467-6494.2007.00447.x 
Whetten, D. A. (1989). What constitutes a theoretical contribution?. Academy of management review, 14(4), 490-495. https://doi.org/10.5465/amr.1989.4308371

Whetten, D. A. (2001). What matters most. Academy of Management Review, 26(2), 175-178. https://doi.org/10.5465/amr.2001.4378008

\section{Copyrights}

Copyright for this article is retained by the author(s), with first publication rights granted to the journal.

This is an open-access article distributed under the terms and conditions of the Creative Commons Attribution license (http://creativecommons.org/licenses/by/4.0/). 